\title{
Front Matter: Volume 7606
}

, "Front Matter: Volume 7606," Proc. SPIE 7606, Silicon Photonics V, 760601 (18 March 2010); doi: 10.1117/12.859331

SPIE. Event: SPIE OPTO, 2010, San Francisco, California, United States 


\section{PROCEEDINGS OF SPIE}

\section{Silicon Photonics V}

Joel A. Kubby

Graham T. Reed

Editors

24-27 January 2010

San Francisco, California, United States

Sponsored and Published by

SPIE

Volume 7606

Proceedings of SPIE, 0277-786X, v. 7606 
The papers included in this volume were part of the technical conference cited on the cover and title page. Papers were selected and subject to review by the editors and conference program committee. Some conference presentations may not be available for publication. The papers published in these proceedings reflect the work and thoughts of the authors and are published herein as submitted. The publisher is not responsible for the validity of the information or for any outcomes resulting from reliance thereon.

Please use the following format to cite material from this book:

Author(s), "Title of Paper," in Silicon Photonics V, edited by Joel A. Kubby, Graham T. Reed, Proceedings of SPIE Vol. 7606 (SPIE, Bellingham, WA, 2010) Article CID Number.

ISSN 0277-786X

ISBN 9780819480026

Published by

SPIE

P.O. Box 10, Bellingham, Washington 98227-0010 USA

Telephone +1 3606763290 (Pacific Time) · Fax +1 3606471445

SPIE.org

\section{Copyright (c) 2010, Society of Photo-Optical Instrumentation Engineers}

Copying of material in this book for internal or personal use, or for the internal or personal use of specific clients, beyond the fair use provisions granted by the U.S. Copyright Law is authorized by SPIE subject to payment of copying fees. The Transactional Reporting Service base fee for this volume is $\$ 18.00$ per article (or portion thereof), which should be paid directly to the Copyright Clearance Center (CCC), 222 Rosewood Drive, Danvers, MA 01923. Payment may also be made electronically through CCC Online at copyright.com. Other copying for republication, resale, advertising or promotion, or any form of systematic or multiple reproduction of any material in this book is prohibited except with permission in writing from the publisher. The CCC fee code is 0277-786X/10/\$18.00.

Printed in the United States of America.

Publication of record for individual papers is online in the SPIE Digital Library.

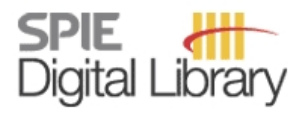

SPIEDigitalLibrary.org

Paper Numbering: Proceedings of SPIE follow an e-First publication model, with papers published first online and then in print and on CD-ROM. Papers are published as they are submitted and meet publication criteria. A unique, consistent, permanent citation identifier (CID) number is assigned to each article at the time of the first publication. Utilization of CIDs allows articles to be fully citable as soon they are published online, and connects the same identifier to all online, print, and electronic versions of the publication. SPIE uses a six-digit CID article numbering system in which:

- The first four digits correspond to the SPIE volume number.

- The last two digits indicate publication order within the volume using a Base 36 numbering system employing both numerals and letters. These two-number sets start with $00,01,02,03,04$, $05,06,07,08,09,0 A, 0 B \ldots 0 Z$, followed by 10-1Z, 20-2Z, etc.

The CID number appears on each page of the manuscript. The complete citation is used on the first page, and an abbreviated version on subsequent pages. Numbers in the index correspond to the last two digits of the six-digit CID number. 


\section{Contents}

ix Conference Committee

xi Introduction

\section{SESSION 1 MATERIALS}

760602 InP overgrowth on $\mathrm{SiO}_{2}$ for active photonic devices on silicon [7606-01]

C. Junesand, Z. Wang, L. Wosinski, S. Lourdudoss, KTH (Sweden)

760604 Optical spectroscopy of Er doped Si-nanocrystals on sapphire substrates fabricated by ion implantation into $\mathrm{SiO}_{2}$ [7606-55]

N. P. Hylton, I. F. Crowe, The Univ. of Manchester (United Kingdom); A. P. Knights, McMaster Univ. (Canada); M. P. Halsall, The Univ. of Manchester (United Kingdom); S. Ruffell, The Australian National Univ. (Australia); R. M. Gwilliam, Univ. of Surrey (United Kingdom)

\section{SESSION 2 DETECTORS}

760607 Preliminary radiation hardness tests of single photon Si detectors [7606-05]

R. Pagano, Univ. of Catania (Italy) and CNR-IMM (Italy); S. Libertino, CNR-IMM (Italy);

G. Valvo, G. Condorelli, B. Carbone, A. Piana, M. Mazzillo, D. N. Sanfilippo, P. G. Fallica, STMicroelectronics (Italy); F. Principato, G. Cannella, Univ. of Palermo (Italy); G. Falci, Univ. of Catania (Italy) and CNR-MATIS (Italy); S. Lombardo, CNR-IMM (Italy)

\section{SESSION 3 LAB-ON-A-CHIP I}

760608 Microfluidic-based detection plafform for on-the-flow analyte characterization (Invited Paper) [7606-06]

P. Kiesel, M. Beck, N. Johnson, M. Bassler, Palo Alto Research Center, Inc. (United States)

760609 Optofluidic biosensing for the study of disease at the molecular level (Invited Paper) [7606-07]

I. M. White, Univ. of Maryland, College Park (United States)

7606 0A Waveguide based optofluidics (Invited Paper) [7606-08]

G. Testa, IREA-CNR (Italy); Y. Huang, Technische Univ. Delft (Netherlands); L. Zeni, Seconda Univ. degli Studi di Napoli (Italy); P. M. Sarro, Technische Univ. Delft (Netherlands); R. Bernini, IREA-CNR (Italy)

\section{SESSION 4 LAB-ON-A-CHIP II}

7606 OB Planar FRET detection from biomolecules on an optofluidic chip [7606-09]

A. Chen, P. Measor, Univ. of California, Santa Cruz (United States); E. J. Lunt, B. S. Phillips, A. R. Hawkins, Brigham Young Univ. (United States); H. Schmidt, Univ. of California, Santa Cruz (United States) 
7606 OC Arrays of SOI photonic wire biosensors for label-free molecular detection [7606-10] A. Densmore, D.-X. Xu, M. Vachon, S. Janz, R. Ma, Y. Li, G. Lopinski, C. C. Luebbert, Q. Y. Liu, J. H. Schmid, A. Delâge, P. Cheben, National Research Council Canada (Canada)

7606 OD A photonic biosensor system on a CMOS chip (Invited Paper) [7606-11] K. L. Lear, R. Yan, Colorado State Univ. (United States)

7606 OE A porous-silicon-based microarray for label-free optical detection of DNA hybridization [7606-12]

I. Rea, G. Coppola, M. Gioffrè, E. De Tommasi, I. Rendina, Institute for Microelectronics and Microsystems, National Council of Research (Italy); A. Lamberti, Univ. of Naples Federico II (Italy); L. De Stefano, Institute for Microelectronics and Microsystems, National Council of Research (Italy)

\section{SESSION 5 WAVEGUIDES I}

7606 OF Applications of subwavelength grating structures in silicon-on-insulator waveguides (Invited Paper) [7606-13]

J. H. Schmid, National Research Council Canada (Canada); P. J. Bock, National Research Council Canada (Canada) and Univ. of Ottawa (Canada); P. Cheben, W. Sinclair, National Research Council Canada (Canada); J. García, Univ. Politécnica de Valencia (Spain); S. Janz, J. Lapointe, G. C. Aers, D. Poitras, Y. Li, G. Lopinski, A. Delâge, A. Densmore, B. Lamontagne, R. Ma, D.-X. Xu, National Research Council Canada (Canada)

7606 OG Germanium implanted Bragg gratings in silicon on insulator waveguides [7606-14] R. Loiacono, G. T. Reed, R. Gwilliam, G. Z. Mashanovich, Univ. of Surrey (United Kingdom); L. O'Faolain, T. Krauss, Univ. of St. Andrews (United Kingdom); G. Lulli, Istituto per la Microelettronica e Microsistemi (Italy); C. Jeynes, Univ. of Surrey (United Kingdom); R. Jones, Intel Corp. (United States)

$7606 \mathrm{OH} \quad$ Effects of annealing silicon ion irradiated rib waveguides with respect to free carrier lifetime [7606-15]

N. M. Wright, A. J. Smith, K. Litvinenko, R. Gwilliam, G. Mashanovich, G. T. Reed, Univ. of Surrey (United Kingdom)

\section{SESSION 6 WAVEGUIDES II}

7606 0J Cantilever couplers for fiber coupling to silicon photonic integrated circuits (Invited Paper) [7606-17]

R. M. Reano, P. Sun, The Ohio State Univ. (United States)

7606 OK Fabrication of porous silicon channel waveguides with multilayer Bragg cladding [7606-18] A. A. Bettiol, E. J. Teo, National Univ. of Singapore (Singapore); S. Prashant, Sri Sathya Sai Univ. (India); X. Boqian, M. B. H. Breese, National Univ. of Singapore (Singapore)

$7606 \mathrm{OL} \quad$ Self-alignment and instability of waveguides induced by forces of guided and radiated fields [7606-19]

A. Mizrahi, K. Ikeda, F. Bonomelli, V. Lomakin, Y. Fainman, Univ. of California, San Diego (United States) 
$76060 \mathrm{M}$ Novel types of silicon waveguides fabricated using proton beam irradiation [7606-20] E. J. Teo, National Univ. of Singapore (Singapore); P. Yang, Univ. of Surrey (United Kingdom); B. Q. Xiong, M. B. H. Breese, National Univ. of Singapore (Singapore); G. Z. Mashanovich, Univ. of Surrey (United Kingdom); Y. S. Ow, National Univ. of Singapore (Singapore); G. T. Reed, Univ. of Surrey (United Kingdom); A. A. Bettiol, National Univ. of Singapore (Singapore)

\section{SESSION 7 MODULATORS}

7606 ON Slow-light photonic crystal switches and modulators (Invited Paper) [7606-21]

D. M. Beggs, T. P. White, Univ. of St. Andrews (United Kingdom); T. Kampfrath, K. Kuipers, FOM Institute AMOLF (Netherlands); T. F. Krauss, Univ. of St. Andrews (United Kingdom)

$760600 \quad$ High-speed silicon optical modulator (Invited Paper) [7606-22]

D. Marris-Morini, G. Rasigade, L. Vivien, P. Crozat, E. Cassan, Institut d'Électronique Fondamentale, Univ. Paris Sud, CNRS (France); P. Lyan, P. Rivallin, J.-M. Fédéli, CEA, LETI, Minatec (France)

7606 OP Power and speed analysis of miniaturized SOI y-branch Mach-Zehnder thermo-optic switches [7606-23]

K. P. Yap, National Research Council Canada (Canada) and Carleton Univ. (Canada); T. Smy, Carleton Univ. (Canada); J. H. Schmid, P. Waldron, A. Densmore, National Research Council Canada (Canada); B. Syrett, Carleton Univ. (Canada); S. Janz, National Research Council Canada (Canada)

$76060 Q$ Design of Ge/SiGe quantum-confined Stark effect modulators for CMOS compatible photonics [7606-24]

L. Lever, Z. Ikonić, A. Valavanis, R. W. Kelsall, Univ. of Leeds (United Kingdom)

7606 OR Ultra-low energy switches based on silicon photonic crystals for on-chip optical interconnects [7606-25]

S. P. Anderson, P. M. Fauchet, Univ. of Rochester (United States)

7606 OS Modulators and photodetectors developed in the framework of the European HELIOS project (Invited Paper) [7606-26]

L. Vivien, J. Osmond, G. Rasigade, D. Marris-Morini, P. Crozat, E. Cassan, Institut d'Électronique Fondamentale, CNRS, Univ. Paris Sud (France); J.-M. Fédéli,

J. F. Damlencourt, CEA, LETI, Minatec (France); D. Thomson, F. Y. Gardes, G. T. Reed, Univ. of Surrey (United Kingdom); D. Van Thourhout, J. Brouckaert, Ghent Univ. (Belgium)

\section{SESSION 8 INTEGRATION}

7606 OT Integrated photonic devices based on silicon photonic wire waveguide platform (Invited Paper) [7606-27]

K. Yamada, H. Fukuda, T. Tsuchizawa, T. Watanabe, H. Shinojima, H. Nishi, S. Park, NTT Corp. (Japan); Y. Ishikawa, K. Wada, The Univ. of Tokyo (Japan); S. Itabashi, NTT Corp. (Japan) 
7606 OU Semiconductor nanomembranes for stacked and flexible photonics (Invited Paper) [7606-29]

W. Zhou, The Univ. of Texas at Arlington (United States); Z. Ma, Univ. of Wisconsin-Madison (United States); H. Yang, L. Chen, W. Yang, Z. Qiang, The Univ. of Texas at Arlington (United States); G. Qin, H. Pang, Univ. of Wisconsin-Madison (United States); S. Chuwongin, D. Zhao, The Univ. of Texas at Arlington (United States)

7606 OV Nanomembrane enabled nanophotonic devices [7606-30]

M. J. Zablocki, Univ. of Delaware (United States); A. S. Sharkawy, O. Ebil, EM Photonics, Inc. (United States); D. W. Prather, Univ. of Delaware (United States)

7606 OW Integrated recirculating optical buffers (Invited Paper) [7606-31]

M. J. R. Heck, G. Kurczveil, E. F. Burmeister, H. Park, J. P. Mack, D. J. Blumenthal, J. E. Bowers, Univ. of California, Santa Barbara (United States)

\section{SESSION 9 RESONATORS}

$76060 X \quad$ Optofluidic ring resonator dye lasers (Invited Paper) [7606-32]

Y. Sun, J. D. Suter, X. Fan, Univ. of Missouri, Columbia (United States)

760610 Numerical investigation of optical resonances in circular grating resonators [7606-35] S. Burger, F. Schmidt, L. Zschiedrich, Zuse Institute Berlin (Germany) and JCMwave GmbH (Germany)

\section{SESSION 10 EMITTERS}

760611 Applications of coherent anti-Stokes Raman scattering in silicon photonics (Invited Paper) [7606-36]

N. Vermeulen, C. Debaes, H. Thienpont, Vrije Univ. Brussel (Belgium)

760612 Using reach-through techniques to improve the external power efficiency of silicon CMOS light emitting devices [7606-37]

M. du Plessis, P. J. Venter, Univ. of Pretoria (South Africa); A. W. Bogalecki, INSiAVA (Pty) Ltd. (South Africa)

760613 New interpretation of photonic yield processes (450-750nm) in multi-junction Si CMOS LEDs: simulation and analyses [7606-38]

L. W. Snyman, Tshwane Univ. of Technology (South Africa); E. Bellotti, Boston Univ. (United States)

760614 Lateral electrical injection into $\mathrm{Si} / \mathrm{SiO}_{2}$ horizontal multislot waveguides [7606-39]

S. P. Anderson, H. G. Yoo, K. Ni, P. M. Fauchet, Univ. of Rochester (United States) 
760615 Waveguide-based optofluidics (Invited Paper) [7606-40]

C. Karnutsch, Hochschule Karlsruhe (Germany); S. Tomljenovic-Hanic, C. Monat, C. Grillet, P. Domachuk, R. McPhedran, B. J. Eggleton, The Univ. of Sydney (Australia); L. O'Faolain, T. F. Krauss, Univ. of St. Andrews (United Kingdom); S. Xiao, N. A. Mortensen, Technical Univ. of Denmark (Denmark)

760616 Photonic crystal microcavities in SOI waveguides produced in a CMOS environment [7606-41]

S. Meister, A. Al-Saadi, B. A. Franke, S. Mahdi, B. Kuhlow, K. Voigt, Technische Univ. Berlin (Germany); B. Tillack, H. H. Richter, L. Zimmermann, IHP GmbH (Germany); V. Ksianzou, S. K. Schrader, Technische Fachhochschule Wildau (Germany); H. J. Eichler, Technische Univ. Berlin (Germany)

POSTER SESSION

760617 Silicon radiative cooler and optical amplifier by light down conversion [7606-28]

V. K. Malyutenko, V. V. Bogatyrenko, O. Yu. Malyutenko, Lashkaryov Institute of

Semiconductor Physics (Ukraine)

760618 Silicon photonics: ready to wafer-bonding fibre grating coupler [7606-42]

C. Kopp, T. Dupont, J.-M. Fédéli, CEA, LETI, Minatec (France); R. Orobtchouk, INL, INSA de Lyon (France)

760619 Light emission from Si LED controlling by a gate voltage and SOS tunneling junction [7606-43] W.-L. Guo, Tianjin Polytechnic Univ. (China) and Tianjin Univ. (China); X.-Y. Li, C.-H. Huang, X.-S. Fu, P.-J. Niu, G.-H. Yang, Tianjin Polytechnic Univ. (China)

7606 1A Athermal and low loss ridge silicon waveguides [7606-44] M. M. Milošević, G. Z. Mashanovich, F. Y. Gardes, Y. Hu, Univ. of Surrey (United Kingdom): A. P. Knights, McMaster Univ. (Canada); N. G. Tarr, Carleton Univ. (Canada); G. T. Reed, Univ. of Surrey (United Kingdom)

7606 1C Taper-integrated multimode-interference-based crossings for silicon wire waveguides [7606-46]

C.-H. Chiu, C.-H. Chen, National Chiao Tung Univ. (Taiwan)

$76061 \mathrm{E}$ Experimental and numerical analysis study of 1-D photonic crystal in Si photonic-wire waveguides [7606-48]

T. Kita, H. Yamada, Tohoku Univ. (Japan)

7606 IF Analysis of all optical logic gate based on photonic crystal multimode interference [7606-49]

H.-S. Kim, T.-K. Lee, G.-Y. Oh, Chung-Ang Univ. (Korea, Republic of); D.-G. Kim, Korea Photonics Technology Institute (Korea, Republic of); Y.-W. Choi, Chung-Ang Univ. (Korea, Republic of)

7606 IG Mode properties of ALD filled slot waveguides [7606-50]

A. Säynätjoki, T. Alasaarela, A. Khanna, A. Tervonen, S. Honkanen, Aalto Univ. (Finland) 
760611 Superfocusing the light through nanosize circular aperture [7606-53]

S. S. Choi, V. K. Jha, O. K. Suwal, Sun Moon Univ. (Korea, Republic of); M. J. Park, Korea Military Academy (Korea, Republic of); N. K. Park, D. S. Kim, Seoul National Univ. (Korea, Republic of)

7606 1J An all-silicon optical transmission system for clock and data transmission [7606-54] P. Ellinghaus, INSiAVA (Pty) Ltd. (South Africa); P. J. Venter, M. du Plessis, Univ. of Pretoria (South Africa); P. Rademeyer, A. W. Bogalecki, INSiAVA (Pty) Ltd. (South Africa)

$76061 \mathrm{~K}$ Formation of Si-nanocrystals in $\mathrm{SiO}_{2}$ via ion implantation and rapid thermal processing [7606-56]

I. F. Crowe, The Univ. of Manchester (United Kingdom); O. Hulko, A. P. Knights, McMaster Univ. (Canada); N. P. Hylton, M. P. Halsall, The Univ. of Manchester (United Kingdom); S. Ruffell, The Australian National Univ. (Australia); R. M. Gwilliam, Univ. of Surrey (United Kingdom)

7606 IL Germanium p-i-n photodiode on silicon for integrated photonic applications [7606-58] J. Mathews, R. Roucka, C. Weng, J. Tolle, J. Menéndez, J. Kouvetakis, Arizona State Univ. (United States)

Author Index 


\title{
Conference Committee
}

\author{
Symposium Chair \\ E. Fred Schubert, Rensselaer Polytechnic Institute (United States) \\ Symposium Cochairs \\ Liang-Chy Chien, Kent State University (United States) \\ James G. Grote, Air Force Research Laboratory (United States)
}

Program Track Chair

Yakov Sidorin, Quarles Brady LLP (United States)

Conference Chairs

Joel A. Kubby, University of California, Santa Cruz (United States)

Graham T. Reed, University of Surrey (United Kingdom)

Program Committee

Laurence W. Cahill, La Trobe University (Australia)

Philippe M. Fauchet, University of Rochester (United States)

L. Cary Gunn, Genalyte, Inc. (United States)

Siegfried Janz, National Research Council Canada (Canada)

Andrew P. Knights, McMaster University (Canada)

Laura M. Lechuga, Centro d'Investigacions en Nanociència i Nanotecnologia (Spain)

Sebania Libertino, Istituto per la Microelettronica e Microsistemi (Italy)

Mario J. Paniccia, Intel Corporation (United States)

Andrew W. Poon, Hong Kong University of Science and Technology (Hong Kong, China)

Holger Schmidt, University of California, Santa Cruz (United States)

Dan-Xia Xu, National Research Council Canada (Canada)

\section{Session Chairs}

1 Materials

Andrew P. Knights, McMaster University (Canada)

2 Detectors

Andrew P. Knights, McMaster University (Canada) 
3 Lab-on-a-Chip I

Holger Schmidt, University of California, Santa Cruz (United States)

4 Lab-on-a-Chip II

Holger Schmidt, University of California, Santa Cruz (United States)

5 Waveguides I

Graham T. Reed, University of Surrey (United Kingdom)

6 Waveguides II

Graham T. Reed, University of Surrey (United Kingdom)

7 Modulators

Philippe M. Fauchet, University of Rochester (United States)

8 Integration

Andrew W. Poon, Hong Kong University of Science and Technology (Hong Kong, China)

9 Resonators

Graham T. Reed, University of Surrey (United Kingdom)

10 Emitters

Joel A. Kubby, University of California, Santa Cruz (United States)

11 Photonic Crystals

Joel A. Kubby, University of California, Santa Cruz (United States)

12 Silicon Photonics: Joint Session with Conference 7616

Mario J. Paniccia, Intel Corporation (United States) 


\section{Introduction}

Silicon has a legendary history as the material of choice for microelectronic integration, but has not been the material of choice for optoelectronic integration. That is now beginning to change with the introduction of monolithic and hybrid silicon photonics. Silicon photonic devices have been demonstrated with the capability to emit, modulate, guide, multiplex/demultiplex, buffer and detect light, and can be combined with microelectronics to form electronic and photonic integrated circuits. Silicon photonic devices such as high-speed (40 GSa/s) analog to digital converts are now being fabricated in commercial CMOS foundries, enabling these devices to leverage the $\$ 500$ billion fabrication infrastructure for integrated circuits. The previous barrier of silicon's indirect bandgap has been overcome through the integration of germanium and III-V materials to form novel in-plane silicon lasers and high-speed (40 Gb/s) modulators which has been achieved via the plasma dispersion effect. The cascaded Raman effect and nano-engineering of crystalline silicon and siliconrich nitride films have also been used to obtain light from silicon and an electrically pumped silicon laser may be on the horizon.

The decrease in waveguide bend radius made possible in silicon-on insulator technology due to its high-index contrast, together with increased levels of optical and microelectronic integration, may lead to a new formulation of Moore's Law for silicon photonics. We are now seeing the convergence of communications and computing directly on-chip with the advent of optical interconnects, driven by the need for smaller and less expensive components that can leverage the infrastructure for CMOS manufacturing. In addition to onchip communications and signal processing, silicon photonics is also being used to form laboratories on a chip with integrated micro-fluidics for low-cost, labelfree biosensing and waveguide-based optofluidics. The past year has been an exciting time for silicon photonics! We hope you will enjoy the papers detailing these advancements that are included in these conference proceedings.

Joel A. Kubby Graham T. Reed 
Downloaded From: https://www.spiedigitallibrary.org/conference-proceedings-of-spie on 26 Apr 2023

Terms of Use: https://www.spiedigitallibrary.org/terms-of-use 